\title{
INTERPERSONAL COMMUNICATION VALUE IN GLOBALIZING COMMUNITY
}

\author{
Irina Shebanova \\ Brest State Technical University, \\ Department of Philosophy and Cultural Studies, \\ Moskovskaja str. 267, Brest, Belarus \\ E-mail: shebanova@mail.ru
}

\begin{abstract}
The attention in this article is paid to social changes in terms of global information processes and the influence of these changes on the appearance of some new forms of socialization. The transformation period of modern society is in many ways determined by informational processes which are based on modern means of communication and technology. The evolution of these technologies transforms interpersonal communication, it being the vital need and universal value.
\end{abstract}

Keywords: communication, socialization, value, virtuality.

doi:10.3846/limes.2010.08

"Asking a question we do not need an answer but want to hear a voice and gain sympathy trying to involve one in the conversation".

Plutarch

\section{Introduction}

Due to globalization processes and transformation of all life spheres many aspects of human existence and social mechanisms have been changing. The transformation period of modern society is in many ways determined by informational processes which are based on modern means of communication and technology, the Internet and mobile telecommunication systems. The evolution of these technologies transforms interpersonal communication, it being the vital need and universal value.

Values are the main linking element of social and cultural systems and, according to an American sociologist Talcott Parsons, “... plays a regulatory role in social processes and relations" (Parsons 1996: 511).

Behind any technology there are people whose priorities depend not only on their professional needs but also on their life program and value system. Advanced humanistic values of a highly-developed individual serve to the social and public activity aimed at the person him/herself, society and nature. The barest necessity of today is to find and set once-lost connection between technical progress and ethic development. Last years have seen quite many publications on value systems in Russian and foreign media. Every five years beginning from 1989 the University of Michigan Institute for Social Research carries out research on value systems on the international scale. Nicolai I. Lapin, Arkadij V. Sokolov, Olga V. Vishtak, Vladimir A. 
Yadov, Vladimir T. Lisovsky, Aleksandr S. Vatoropin, Valerij A. Popov, Tatjana G. Kalachova, Tatjana V. Kovaliova, and others study youth value systems. Belarusian researchers, David G. Rotman, Sergej A. Shavel, Evgenij. M. Babocov, Svetlana V. Lapina (Minsk), Georgij M. Gribov (Brest), Mikhail U. Sumach (Grodno), Arkadij B. Rusetsky, Leonid A. Gaschenko, Irina A. Kapitonova (Vitebsk) pay much attention to studentship and their value preferences.

Issues devoted to values and behavioural predilections of students, the most dynamic and avant-garde group of population, have been studied in the framework of the Republican Scientific and Research Programme "Dynamics of the youth value system in Belarus" where the author has taken part (2).

This article focuses on communication relevance, motivations for communication needs, interpersonal communication, and communication means and models in today's globalizing world. Communication whether it is taken as a value or not is always a dialogue, i.e. a choice of the two interacting parties to reach understanding. Interpersonal communication is interrelation experienced and recognized to a variable extend and based on various emotional states and psychological patterns. That is why unlike business relations interpersonal communication is sometimes referred to as emotional or expressive.

\section{Virtuality as a universal characteristic of informational society}

A manner of talking is the second important after clothes style that shapes a person's first impression of his/her interlocutor. Verbal and visual nonverbal characteristics define communication itself as well as its evaluation when people get in the direct contact. Communication participants evaluate anatomic features (height, hair colour, etc.) physiological characteristics (good breath, circulation of the blood, sweat), functional (bearing, posture, gait) and linguistic verbal and nonverbal (speech rate, audibility, facial expression and gestures, bodily movement) peculiarities.

Social status presupposes socially correlating appearance: proper clothing, footwear, and other accessories while psychologists and sociologists mark out additional characteristics, such as extralinguistic (timbre and the pitch of a voice, etc.) and proxemic ones (mutual sympathy). The specialist considers them more informative than physical appearance. Unlike transportation systems for travel in geographical space the means for virtual communication, virtual travel and virtual presence are advancing and spreading headily nowadays. That is why not only communication intensity but also an increasing due to the modern communication means and technologies scale of interaction between various communities and participants as well as communication participant identification, and development of new communication forms have arisen scientific interest.

The term virtual (Latin virtus - imaginary) was initially introduced by quantum physicists to define an ephemeral elementary particle appearing and existing only in the interaction with other particles. Later on the term was applied to threedimensional macro models. And nowadays it has become a universal characteristic of 
information communication activity as it is. The distinction between real and virtual becomes vague in the information community. The basic distinction of virtual communication is indirectness. Virtual communication is realized by means of a technical device. There are two or more participants involved in the process of exchanging information with the help of virtual communication technologies.

The main characteristic features of virtuality are as follows:

a) actuality: virtual objects "exist here and now";

b) portability: virtual objects existence principles differs from the principles of the presenting reality;

c) interactivity: virtual objects can interact with the presenting reality and be independent from it;

d) ephemerality: virtual objects are artificial and changeable;

e) exposure non-materiality: being non-material virtual objects can at the same time produce results which are characteristic of the objective world;

f) fragmentariness: free entrance and exit to virtual reality ensures its optional interruption and renewal.

Due to evoking and universal application of information and communication technologies we can speak about the development of virtual space where communication processes take place. According to Paul J. Kelly, in virtual reality you can be whoever you like, look whatever the way you want, you have no limits of real world (Kelly 1999). In virtual communication external physical and social characteristics disappear or become irrelevant to establishing informational contact. Virtual communication provides an individual with new possibilities for experiencing personal freedom. The conditions, time and place of communication are of little importance. Only the choice between "on” and "off” becomes relevant. Diminishing of communication barriers is one of the factors that make virtual communication more attractive for people. The barrier of shame and guilt resulting from a negative self-appraisal is overcome in indirect computer communication. Hidden personality is expressed; secret wishes and motivations are satisfied in the process of virtual communication. The fear barrier, that can paralyze not only the activity itself but also a communication ability, disappears when one talks to "nobody", hopes for "no-matter-whose" support and understanding "God-knows-who". In the virtual world the following types of barriers do not work:

- prejudice, a pre-concieved judgement or attitude towards someone or something;

- contempt, resulted from a cultural gap or a lack of accomplishment;

- disgust, caused by an individual psychophysical behavior pattern (unpleasant manners, habits, bad personal hygiene).

But, perhaps, the most attractive aspect of virtual communication is disappearing speech barriers such as poor vocabulary, monotony, a babbled voice, a repulsive tone of voice, and improper speech etiquette.

However, virtual communication space requires particular skills in overcoming specific information barriers: technical, psychophysiological (concentration ability, 
typing speed) symbolic, semantic (the ability to identify symbols and reinstate them in a particular context, specific vocabulary usage), and others. But the desire to find communication partners is stronger than fear of technology and new rules.

\section{Language forms transformation in virtual communication}

In the modern virtual space we can now observe a gradual disappearance of statusoriented communication. You as a singular form of addressing is dominating over you as a plural form of addressing. Perhaps it is due to the transition onto another level of intimacy and reflects interaction intensification and subjectification, a greater degree of spontaneity and sincerity of interlocutors. That is why attention is no longer paid to the image as well as etiquette and role demands, your own fears and defenses. Emotionally saturated common reality of realizing the key existential problems and their living through now and here is formed. Such communication makes us psychologically closer and the transition to you singular means reaching the level of mutual understanding and not only on a rational basis but to a large extent on the basis of empathy.

Cyber-ethics, as a field of applied philosophy, is just beginning to form. The system of oral regulators is now at the initial stage and far from every participant of the virtual communication space follows it. We can say that rules and norms are being formed spontaneously and differ from epistolary ethics which used to demand in letters essentially formalities which later transformed into the habits of using neatly legible handwriting, not using short phrases (disrespect) or being too verbose (familiarity), not using just one letter with a full stop instead of the signature, not forgetting to put down your address and the date, choosing the right tone of the letter, etc. Modern young people communicate in the web space by e-mail, in chartrooms with the help of SMSs working out new ethic rules and a new peculiar language.

In the world of the Internet and mobile communication we can not observe rigid demands to write grammatically - there are too many misprints and mistakes. And it does not worry anybody in the Web. A new style of writing can be characterized by accuracy, brevity and concentration as well as absence of well known ethic norms and clichés which are obligatory in the situation of visual and verbal communication, absence of the fear of a personal contact, of the fear of being perceived as an ignorant person. Most probably it is a false freedom of writing ungrammatically.

The new language of communication differs to a large degree from the literary one and sometimes consists of shortenings, capital letters of some phrases very often English ones. These are so called acronyms - peculiar symbolic shortenings of full phrases and sentences which enable expressing your thoughts and feelings in a shorter time. The examples of such acronyms in the web are numerous: IMHO - in my humble opinion, pls - please, BRB - be right back.

Numbers are very often used as well as acronyms. The number 4 has a double meaning - it is used as the Russian letter $u$ and as for - 4you - for you or $2 y$ - to you. The same principle is applied in the name of a popular pop group Ума2рман. Thank you can be written as than $X$ or $10 X$; goodbye - bb from bye bye, etc. The appearance 
and usage of such a language is dictated by the principle of convenience and economizing your efforts - it is a possibility to express you thoughts and feelings in a shorter time.

Modern young people communicate with the help of SMSs in the mobile telephone world. A great advantage of theirs is their accuracy and brevity which include a big informational volume, the speed of transmitting and receiving information. We can consider $S M S$ s exchange as an improved alternative to telegrams. What is especially attractive here - your own tempo, interactivity, the possibility of receiving information at any time in any place. Not less important is the possibility of saving the selective information in your mobile phone.

The emotional component is always referred to as a most difficult one in virtual communication. But the absence of intonation and facial expression does not mean the absence of feelings. Those communication patters that are transmitted with the help of non-verbal means in the process of real communication are replaced by a text message, different grammatical marking and so called "smiles". In this way virtual communication can be considered as some kind of hybrid of the oral and written speech and nonverbal components can be expressed by means of graphical forms that are regarded as an interactive competence of the user.

\section{The significance of interpersonal communication for students}

We all seek communication either consciously or unconsciously. Communication is considered to be a natural accompaniment of the human life. It is present in it from the very first minutes of our life. Psychological development of the child starts with communication. This is the first kind of a social activity. The quality of a personality depends on it. Deprivation of communication is the worst punishment after deprivation of life. But in contrast to other values (political, material, ethical, etc.) the value of communication is not realized and is not marked as exceptionally meaningful. In the frame of the above-mentioned scientific research a social survey was carried out with the view of identification of the value orientation hierarchy among students. The importance of the communication value is the following:

\begin{tabular}{l|c|c|c|c}
\hline Country & Belarus & Germany & Poland & Portugal \\
\hline Factor place & 11 & 12 & 13 & 16 \\
\hline
\end{tabular}

Except such undoubtedly basic values as "health”, "family”, "love” a higher place than "communication" is occupied by such factors as "human rights guaranty", "respect of other people", "psychological composure", " the possibility to realize your talents" and some others.

Perhaps the reason for a comparatively low rating of the communication value is in its habitualness and availability as we do not realize the value of the air in everyday life situations. But some external factors point to the unconscious demand and vital necessity for having assurance in the possibility of communication. For example, 
necessary attributes of a student coming to the lecture are notes, a pen and a mobile phone even if its sound signal is switched off. The possession of mobile communication means to some extent guarantees the possibility of always being in touch and being in the "information network". It can be considered as a peculiar way of escaping the fear of being lost, of dropping out of the social interaction network.

A small-scale sociological survey among some groups of students showed that only a very small number of them switch off their mobiles completely and only for the night. Usually they switch off only sound and vibro signals. The fear of young people to switch temporary from "on" to "off" - is the fear of being placed outside the social interconnection network. For many elderly people such fear is related to the pension period. It can be also regarded as a peculiar breaking up and dropping from the habitual interaction network. If another well developed social network already exists by that time in which the person is involved (family, grandchildren, colleagues, etc.) - it diminishes the fear of retirement. Young people have been offered to answer the question what they feel when they do not have their mobile phones with them. The most frequently repeated answers were: "alertness - what if something happens", "helplessness - feeling lost”, "as if something is missing”, "as if you had left one part of yourself", "it is bad as I do not know the time". And only 7 people out of 50 respondents have written that they remain calm. Two students have written they do not have mobile phones and do not use them.

Who do participants of the mobile communication first of all need the interconnection with? First of all with their friends, then their parents or any other person they work with. The above-mentioned are so called agents of primary socialization. Therefore, a new form of a person's socialization takes place by means of being included into the mobile network.

\section{Conclusions}

Virtual space, created by active use of new communication technologies can be considered as a new socio-cultural environment in which its own peculiar values are evolving, certain communication rules are functioning, its own language is working. Entering this new socio-cultural space takes place as a new form of a modern person's socialization.

The possibility to remain to a certain extent anonymous thanks to mediation of the computer or SMSs leads to the psychological risk reduction in the process of communication. As a result it becomes possible to express your most concealed opinions, to reveal depressed sides of your personality, to satisfy your secret desires and intentions in the process of virtual communication.

Due to the initial anonymity and invisibility, which are the consequence of the visual image absence, a person creates his/her own virtual personality according to his wishes and possibilities in the network communication. Perhaps, the main reason for the virtual communication popularity is its contacts voluntariness and desirability combined with the possibility of "leaving" at any moment. 
"Sociality" of virtual space differs from the habitual "real” one: peculiar mechanisms not acceptable in the real society function here, virtual communication take place in a specific environment and its peculiarities influence their functioning.

Sociality of the World Web lies in the fact that it is impossible to imagine it without people. The virtual world was created by the human being and for the human being and if in the real world a human being is only a part of the world there is nothing except for human beings and information and communication created by them in the virtuality.

The value of the Internet and mobile communication in the modern society lies in their actual demand and not only for business relationships but also for realization of need in interpersonal communication. Interpersonal communication remains the most important human value acquiring new forms and ways of interactivity.

\title{
References
}

Gribov, G. 2006. The World of Youth Values: The Past, Present, the East, the West. Brest: BrSTU Publishing House.

Kelly, P. 1997. "Human Identity Party: Who Are You?" [online], [Last access: 17-05-2000]. Available from Internet: <http://flogiston.df.ru./projects/articles/strategy.shtml>.

Parsons, T. 1996. "The Functional Theory of Culture", in Dobrenkov, V. I. (Ed.). The American Sociological Thought. Moscow: The edition of the International University of Business and Management, 560.

\section{TARPASMENINĖS KOMUNIKACIJOS REIKŠMĖ GLOBALIZUOTOJE BENDRUOMENĖJE}

\author{
Irina Shebanova
}

Santrauka

Šiame straipsnyje dèmesys sutelkiamas i socialinius pokyčius globaliųjų procesų sąlygomis ir i šiu pokyčių įtaką pastebimoms naujoms socializacijos formoms. Moderniosios visuomenès transformacijos laikotarpis yra nulemtas informaciniu procesų, kurių pagrindą sudaro modernios komunikacijos priemonès ir technologijos. Šių technologijų evoliucija keičia tarpasmeninę komunikaciją, nulemdama jos esmini poreikị ir universalią vertę.

Reikšminiai žodžiai: komunikacija, socializacija, reikšmè, virtualumas.

Received 28 January 2010, accepted 1 February 2010 